\title{
ESTERASE ACTIVITY IN HOMOGENATES OF Helicoverpa armigera (HUBNER) (Lepidoptera: Noctuidae) EXPOSED TO DIFFERENT INSECTICIDES AND THE BEHAVIORAL EFFECT
}

\author{
ATIVIDADE ESTERASE EM HOMOGENATOS DE Helicoverpa armigera (HUBNER) \\ (Lepidoptera: Noctuidae) EXPOSTOS A DIFERENTES INSETICIDAS E O EFEITO \\ COMPORTAMENTAL
}

\author{
Eliane CARNEIRO' ${ }^{1}$; Luciana Barboza SILVA ${ }^{1}$; Patricia PAIVA ${ }^{2}$; \\ Thiago Henrique NAPOLEÃO ${ }^{2}$; Gabriel dos Santos CARVALHO' ${ }^{1}$;leidyane Novais LOPES ${ }^{1}$; \\ Bruno Ettore PAVAN ${ }^{3}$ \\ 1. Universidade Federal do Piauí, Campus Professora Cinobelina Elvas (UFPI/CPCE), Bom Jesus, PI, Brasil. \\ elian.cbs@ hotmail.com; 2. Universidade Federal de Pernambuco (UFPE), Recife, PE, Brasil. 3. Faculdade de Engenharia, Universidade \\ Estadual Paulista (UNESP), Ilha Solteira, SP, Brasil.
}

\begin{abstract}
The toxicity of some insecticides to Helicoverpa armigera was studied through sublethal effects, evaluating the enzymatic activity of esterase and the behavioral response. The commercial formulation of insecticides selected were chlorpyrifos, spinosad, indoxacarb, chlorantraniliprole, lambda-cyhalothrin and Bacillus thuringiensis, corresponding the most used by farmers to control of $\mathrm{H}$. armigera. To determine the esterase activity, the larvae were fed with soybean leaf discs dipped in insecticide solution using the lethal concentration $\left(\mathrm{LC}_{50}\right)$. For the behavioral response, filter paper were immersed in three concentrations of insecticides $\left(\mathrm{LC}_{50}, \mathrm{LC}_{95}\right.$ and recommend dose.), then the behavior of the larvae observed in Videomex-One. The results for the enzymatic activity showed an increase in the activity of the esterase, with variation along the treatments and the time of exposure of the insects to the insecticides. With exception of spinosad, other insecticides showed an increase in EST- $\alpha$ activity, 6 and 24 hours after contact of caterpillars with insecticide.Different behavioral patterns of walking (walking distance, walking speed and resting time) were observed for $H$. armigera exposed to different insecticides. $H$. armigera exposed to chlorpyrifos, lambdacyhalothrin and $B$. thuringiensis insecticides show greater esterase activity. Regarding walking behavior, the results confirms enzymatic activity, where $H$. armigera have behavioral alteration after exposure to insecticide.
\end{abstract}

KEYWORDS: Detoxification. Enzymatic activity. Resistance. Sublethal effects.

\section{INTRODUCTION}

Helicoverpa armigera (Hübner) (Lepidoptera: Noctuidae) is considered the most important agricultural pest in Europe, Asia, Africa and Oceania (KRITICOS et al., 2015; CUNNINGHAM; ZALUCKI, 2015). In South America, this insect was considered a quarantine pest up to 2012/13 crop, when a high infestation was observed, in countries where agricultural production is intense, such as, Brazil, Argentina and Paraguay, causing damages in soybean, corn and cotton (HIROSE; MOSCARDI, 2012; SPECHT et al., 2013; SENAVE, 2013; MURÚA et al., 2014).

Different management techniques are used to control $H$. armigera caterpillar, mainly chemical insecticides (FORRESTER et al., 1993). Pest species has been under strong selective pressure, thus, increasing the cases of resistance. There are documented cases of resistance by $H$. armigera to the main chemical groups, such as, pyrethroids, organophosphorus, carbamates, organochlorides, spinosad and Bacillus thuringiensis (GUNNING; EASTON, 1994; GUNNING et al., 1995; GUNNING et al., 2005).

Resistance may appear as a result of a genetic change that alters the physiological, morphological, biochemical or behavioral features of a given population. The biochemical mechanisms can be detoxification by enzymes, including esterases, transferases and oxidases; physiological mechanisms, such as reduced penetration and transport of the pesticide to the target (nervous system); and behavioral mechanisms, in which insects avoid as treated areas due to the irritating and repellent effects of insecticides (CHAREONVIRIYAPHAP et al., 2013; NANSEN et al., 2016).

The enzyme-mediated detoxification occurs by changing the reaction speed and hydrolysis of the compounds in a wide variety of allelochemicals, and reduces these compounds into less harmful 
substances to the insect (MCCAFFERY, 1998). Insects detoxify insecticides by using enzymes, such as cytochrome P450, esterases ( $\alpha-$ and $\beta$-) or glutathione S-transferases (GSTs) among others GST plays a role in DDT resistance, while nonspecific esterase mostly involved in resistance to organophosphates, carbamates and sometime to pyrethroids (LI et al., 2007).

In behavioral resistance, insects may avoid ingesting and oviposition on leafs of plants with insecticides, in addition to being able to detect changes in the environment through chemoreceptor and mechanoreceptor organs located on the antennas and legs (COOPERBAMD; ALLAN, 2009; MCALLISTER et al., 2012). This resistance is defined as behavioral resistance since the insect develops an ability to avoid doses of the insecticide that would be lethal. Helicoverpa armigera has presented resistance to the main chemical groups used to control this species in different countries, even though it is a species of pest recently observed in Brazil, it emphasizes if the importance of information on the control and behavior of this pest species (HECKEl et al., 1998; FITT; WILSON, 2000; DOWNES et al., 2010; TABASHNIK et al., 2012; TAY et al., 2013). Thus the objective was to evaluate the enzymatic activity of esterase and the behavioral response of $H$. armigera exposed to the main insecticides used for its control.

\section{MATERIAL AND METHODS}

\section{Insect mass rearing}

Larvae of $H$. armigera were collected in soybean crops in the state of Piauí, taken to the Plant Sciences Laboratory of the Federal University of Piauí, Campus-Bom Jesus, after sorting, the insects were kept on an artificial diet adapted Kasten Júnior et al. (1978), wheat germ (237 g), beer yeast $(152 \mathrm{~g})$, ascorbic acid (15 g), sorbic acid (4.45 g), nipagine (9.45 g), agar (12.5 g) (propionic acid $41.8 \%, 4.2 \%$ phosphoric acid and 54\% water) was added to the pupal stage. The pupae were transferred to Petri dishes covered with moist paper towels in PVC cages $(40 \mathrm{~cm} \times 30 \mathrm{~cm})$, covered with sheets of paper until adulthood. Adults were fed honey solution $(10 \%)$ and kept under controlled conditions (temperature $25 \pm 2{ }^{\circ} \mathrm{C}, 60 \pm 5 \% \mathrm{RH}$, 12:12 (L:D)) for oviposition. The eggs were collected and stored in plastic bags until hatching. A proportion of the newborn caterpillars were maintained on artificial diet and a proportion used to perform the bioassays (F2). For confirmation of the species, samples of the population were sent for identification by the Biological Institute (Result of Phytosanitary Diagnosis 02202/2013).

\section{Dose-response bioassays}

The Bioassay to determine the concentration-response curves, constituted of six treatments with six doses per treatment, the doses used correspond to $0 ; 10 ; 25 ; 50 ; 75$ and $100 \%$ of the recommended doses in the field for $H$. armigera (Table 1).The insecticides were diluted in water, then soybean leaf discs (diameter $5 \mathrm{~cm}$ ) were immersed for three seconds. After 30 min they were offered to 80 third instar larvae by concentration, which were kept under controlled conditions (temperature $25 \pm 2{ }^{\circ} \mathrm{C}, 60 \pm 5 \% \mathrm{RH}, 12: 12$ (L:D)) for a period of $48 \mathrm{~h}$. Subsequently, assessment of larval mortality was performed, considering dead individuals being touched with tweezers in the last abdominal segments not responding with coordinated movements.

Table 1. Products, active ingredients and doses of the insecticides used to determine the response dose curve for Helicoverpa armigera

\begin{tabular}{lllllllll}
\hline Product & Active ingredient & i.a.g. $\mathrm{L}^{-1}$ & \multicolumn{7}{l}{ Doses for L.ha } & \\
\hline B. thuringiensis & B. thuringiensis & 33.6 & 0 & 0.07 & 0.0150 & 0.35 & 0.52 & 0.7 \\
Chlorantraniliprole & Diamide & 200 & 0 & 0.01 & 0.025 & 0.05 & 0.075 & 0.1 \\
Chlorpyrifos & Organophosphorus & 480 & 0 & 0.16 & 0.375 & 0.750 & 1.12 & 1.5 \\
Indoxacarb & Oxadiazine & 150 & 0 & 0.004 & 0.01 & 0.02 & 0.03 & 0.4 \\
Lambda-cyhalotrin & Pyrethroid & 250 & 0 & 0.015 & 0.037 & 0.075 & 0.12 & 0.15 \\
Spinosad & Spinosyn & 400 & 0 & 0.008 & 0.02 & 0.04 & 0.06 & 0.08 \\
\hline
\end{tabular}

i.a. g. $\mathrm{L}^{-1}=$ active ingredient in grams per liter

\section{Enzymatic bioassay}

The assays were conducted in the Plant Science laboratory of the Federal University of Piauí, Campus - Bom Jesus, PI, under control conditions (temperature $25 \pm 2^{\circ} \mathrm{C}, 60 \pm 5 \% \mathrm{RH}, 12: 12$ (L:D)). The design used was the $7 \mathrm{x} 4$ factorial (seven treatments and four times), 240 third instar caterpillars were used per treatment, 60 third instar caterpillars for each time evaluated.

Third instar caterpillars were individualized and fed with soybean leaf discs $(5 \mathrm{~cm}$ in diameter) soaked in the dose-response bioassays $\left(\mathrm{LC}_{50}\right)$ for 3 
seconds under gentle agitation and then dried in the open air. The $\mathrm{LC}_{50}$ used for enzymatic assays were obtained from the dose response curve and are shown on Table 2. Soybean leaf discs wet in distilled water were used as treatment control.

The evaluations were conducted at four times: 1, 6, 12 and 24 hours after being exposed to the insecticides. After each time, the caterpillars that lived were frozen using liquid nitrogen in $2-\mathrm{mL}$ Eppendorf tubes and maintained on a freezer at $20^{\circ} \mathrm{C}$.

\section{Preparation of the enzymatic extract}

The enzymatic assays were conducted in the Biochemical laboratory of the Federal University of Pernambuco, Campus - Recife, PE. To prepare the enzymatic extracts the tubes containing the insects were thawed and kept on ice as larvae were homogenized in $0.1 \mathrm{M}$ phosphate buffer solution of $\mathrm{pH}$ 7.2. The homogenized materials were centrifuged for $10 \mathrm{~min}$, at $9.000 \mathrm{~g}$. The supernatant was kept on ice and used to biochemical analysis.

\section{Total Protein}

The amount of total protein was measured according to the method described Lowry et al. (1951). A standard curve was conducted for bovine serum albumin (BSA), with values between 0 and $500 \mathrm{mg}$. A portion of $20 \mu \mathrm{L}$ of the enzymatic extract was distributed in duplicates on test tubes, then, 180 $\mu \mathrm{L}$ of water and $1.000 \mu \mathrm{L}$ of the $\mathrm{C}\left[\left(\mathrm{NaCo}^{3}\right.\right.$ anhydrous $+\mathrm{NaOH})+($ copper sulphate + sodium citrate)] solution were added and incubated for 10 min. Then, $100 \mu \mathrm{L}$ of the E (Folin and Ciocalteu's phenol + distilled water at 1:1) solution was added, and all the tubes were incubated for $30 \mathrm{~min}$. The absorbance of the samples was determined at 720 $\mathrm{nm}$ on a UV-visible spectrophotometer.

\section{Alpha esterase (EST - $\alpha)$ and beta esterase (EST - 乃) enzyme}

Portions of $30 \mu \mathrm{L}$ of the enzymatic extract were transferred to test tubes. Then, $500 \mu \mathrm{L}$ of the specific substrates were added for EST- $\alpha(0.3 \mathrm{mM}$ of alpha-naphthyl acetate on $0.1 \mathrm{M}$ of $\mathrm{Kl}$ phosphate at $\mathrm{pH} 7.2$ containing $1 \%$ of acetone) and for EST- $\beta$ ( $0.3 \mathrm{mM}$ of beta-naphthyl acetate on $0.1 \mathrm{M}$ of $\mathrm{Kl}$ phosphate at $\mathrm{pH} 7.2$, containing $1 \%$ of acetone) on the respective tubes. The tubes were incubated for $20 \mathrm{~min}$ at $30^{\circ} \mathrm{C}$. Then, $0.1 \mathrm{~mL}$ of the Fast blue $\left(\right.$ Sigma $\left.^{\circledR}\right), 0.3 \%$ dye were added, homogenized and centrifuged for $5 \mathrm{~min}$. at $3.000 \mathrm{~g}$, at $28{ }^{\circ} \mathrm{C}$. The absorbance of the supernatant was recorded at 590 $\mathrm{nm}$ on a UV-visible spectrophotometer. The results were expressed on $\mathrm{nmol} / \mu \mathrm{g}$ protein/min. The assays were conducted on duplicates.

\section{Bioassay to detect effects on behavior}

The behavioral bioassays were carried out in arenas half-treated with an insecticide solution and the other half with distilled water. Filter papers (Whatman no.1) with dried, chlorpyrifos, spinosad, indoxacarb, chlorantraniliprole, lambda-cyhalothrin and B. thuringiensis (applied as $1 \mathrm{~mL}$ solution and let dry for $30 \mathrm{~min}$ and lethal concentrations $\left(\mathrm{LC}_{50}\right.$ and $\mathrm{LC}_{95}$ ) and recommended dose were placed on Petri dishes (9 $\mathrm{cm}$ diameter). The inner walls of each Petri dish were coated with Teflon to prevent insects from escaping. Ten arenas with individual insects were used for each insecticide in each behavioral bioassay (half-treated arenas), and no mortality was observed within the exposure time used for the behavioral bioassays.

The movement of each insect within the arena during the $30 \mathrm{~min}$ trial was recorded and digitally transferred to a computer using an automated video tracking system equipped with a CCD camera (Videomex-One, Columbus Instruments, Columbus, OH, USA). The video images of the arenas were maintained either undivided, for the behavioral bioassay with the arena, divided into two symmetrical zones - one untreated and the other treated with the insecticide, for the behavioral bioassay with half-treated arenas. The parameters calculated for the half-treated arenas were walking distance $(\mathrm{cm})$, velocity $(\mathrm{cm} / \mathrm{s})$, time spent walking (i.e., walking time; s), time spent immobile (i.e., resting time; s), and time spent stationary while participating in non-forward motion (i.e., stationary time; s).

The design was completely randomized in the factorial scheme (product $\mathrm{x}$ dose $\mathrm{x}$ area), and there were 6 treatments with 3 concentrations and 10 replicates for each treatment, in which each replicate consisted of one caterpillar, and at each repetition, Petri dishes, Filter papers and caterpillars have been replaced. The tests to detect the behavioral resistance of $H$. armigera were conducted on a laboratory, at a temperature of $25^{\circ} \mathrm{C}$, between 8:00 $\mathrm{h}$ and 18:00 $\mathrm{h}$.

\section{Statistical Analyses}

The mortality results obtained were subject to Probit analysis (FINNEY, 1971) using the PROC PROBIT procedure of the System of Statistical Analyses SAS (2002) program, creating the concentration-mortality curve.

Data obtained for the biochemical analysis and walking behavioral characteristics were subject 
to analysis of variance, and the means were compared with Tukey's test, at 5\% of significance using PROC GLM (SAS, 2002).

The walking behavioral characteristics in the treated arena were subject to variance analysis and average test (Tukey's Test) PROC GLM (SAS, 2002).

\section{RESULTS}

The insecticide indoxacarb have high toxicity to $H$. armigera, as it reached $95 \%$ mortality in a concentration lower than the recommended one, whereas for the other insecticides the recommended dose was not sufficient to reach such mortality levels (Table 2). Chlorpyrifos, which would require a dose $61 \%$ above the dose recommended for the control of this species.

The alpha-esterase activity showed increase in all treatments after 1 hour of exposure to the treatments when compared to the control, with highlight to chlorpyrifos that was larger to the other treatments. In the activity evaluated at 6 hours $B$. thuringiensis was the treatment that presented greater Alpha-esterase activity, followed by chlorpyrifos. At 12 and 24 hours lambdacyhalothrin and chlorantraniliprole showed greater activity (Table 3).

Table 2. Toxicity of different insecticides used to control Helicoverpa armigera

\begin{tabular}{lccccc}
\hline \multirow{2}{*}{ Treatment } & \multicolumn{2}{l}{ Lethal Concentration L.ha } & & & \\
\cline { 2 - 3 } & $\mathbf{L C}_{\mathbf{5 0}}(\mathbf{I C ~ 9 5 \% )}$ & $\mathbf{L C}_{\mathbf{9 5}}(\mathbf{I C ~ 9 5 \%})$ & Slope (SD) & $\mathbf{X}^{\mathbf{2}}$ & $\mathbf{P}$ \\
\hline B. thuringiensis & $0.22(0.15-0.30)$ & $0.77(0.51-1.76)$ & $1.54(0.32)$ & 10.89 & 0.62 \\
Chlorantraniliprole & $0.004(0.00-0.07)$ & $0.71(0.15-2.46)$ & $0.66(0.30)$ & 18.33 & 0.14 \\
Chlorpyrifos & $0.95(0.16-1.49)$ & $2.44(1.59-4.55)$ & $2.04(0.63)$ & 20.85 & 0.08 \\
Indoxacarb & $0.003(0.00-0.02)$ & $0.12(0.02-0.33)$ & $0.53(0.23)$ & 35.72 & 0.15 \\
Lambda-cyhalotrin & $0.062(0.04-0.09)$ & $1.03(0.41-10.5)$ & $1.35(0.31)$ & 17.48 & 0.18 \\
Spinosad & $0.01(0.00-0.02)$ & $0.11(0.05-1.13)$ & $0.77(0.33)$ & 42.79 & 0.04 \\
\hline
\end{tabular}

$\mathrm{DP}=$ standard deviation; $\mathrm{X}^{2}=$ chi-square $; \mathrm{IC}=$ confidence interval; $\mathrm{P}=$ probability

Table 3. Alpha-esterase activity (Mean $\pm \mathrm{SE}$ ) of the enzymatic extract of Helicoverpa armigera exposed to $\mathrm{LC}_{50}$ of different insecticides

\begin{tabular}{lllll}
\hline \multirow{2}{*}{ Treatments } & \multicolumn{4}{l}{ Alpha-esterase Activity U/mg of protein } \\
\cline { 2 - 5 } & $\mathbf{1 h}$ & $\mathbf{6 ~ h}$ & $\mathbf{1 2} \mathbf{~ h}$ & $\mathbf{2 4} \mathbf{~ h}$ \\
\hline Control & $2.04(0.29) \mathrm{Ca}$ & $1.66(0.05) \mathrm{Ca}$ & $3.75(0.07) \mathrm{Da}$ & $2.42(0.18) \mathrm{Da}$ \\
B. thuringiensis & $6.27(0.46) \mathrm{Bb}$ & $12.41(0.17) \mathrm{Aa}$ & $8.43(0.70) \mathrm{Bb}$ & $6.03(0.49) \mathrm{BCb}$ \\
Indoxacarb & $5.83(0.10) \mathrm{Bb}$ & $8.62(1.18) \mathrm{Ba}$ & $5.48(0.24) \mathrm{CDb}$ & $7.41(0.73) \mathrm{Bab}$ \\
Chlorpyrifos & $12.02(1.67) \mathrm{Aa}$ & $9.67(0.40) \mathrm{ABab}$ & $5.77(021) \mathrm{BCDc}$ & $8.36(0.67) \mathrm{ABb}$ \\
Lambda-cyhalotrin & $6.76(0.15) \mathrm{Bb}$ & $7.18(1) \mathrm{Bb}$ & $17.52(0.89) \mathrm{Aa}$ & $6.62(1) \mathrm{BCb}$ \\
Chlorantraniliprole & $5.72(0.31) \mathrm{Bb}$ & $7.43(0.73) \mathrm{Bb}$ & $7.32(0.75) \mathrm{BCb}$ & $10.56(0.81) \mathrm{Aa}$ \\
Spinosad & $5.53(0.85) \mathrm{Ba}$ & $3.73(0.30) \mathrm{Ca}$ & $4.63(0.61) \mathrm{CDa}$ & $4.5(0.29) \mathrm{CDa}$ \\
\hline $\mathrm{CV}(\%)$ & & & & 16.71
\end{tabular}

Means followed by the same upper-case letter on the column and lower-case letter on the row do not differ according to Tukey's test at $p \geq 0.05$.

Lambda-cyhalothrin, B. thuringiensis, chlorpyrifos and chlorantraniliprole showed increased beta-esterase activity. Regarding the evaluation times of the activity, B. thuringiensis presented increase of the beta esterase activity after 1, 6 and 12 hours. Chlorantraniliprole presented increased activity after 6 hours of evaluation (Table 4).

The distance walked by Helicoverpa armigera evaluated in $\mathrm{LC}_{50}$ was higher for $B$. thuringiensis and lambda-cyhalothrin treatment, $\mathrm{LC}_{95}$ spinosad, in DR (Recommended Dose) chlorpyrifos and spinosad (Figure 1). 
Table 4. Mean beta-esterase (Mean $\pm \mathrm{SE}$ ) activity of the enzymatic extract of Helicoverpa armigera exposed to $\mathrm{LC}_{50}$ of different insecticides

\begin{tabular}{lllll}
\hline \multirow{2}{*}{ Treatment } & \multicolumn{4}{l}{ Beta-esterase Activity U/mg of protein } \\
\cline { 2 - 5 } & $\mathbf{1 ~ h}$ & $\mathbf{6 ~ h}$ & $\mathbf{1 2 ~ h}$ & $\mathbf{2 4} \mathbf{~ h}$ \\
\hline Control & $0.39(0.16) \mathrm{Da}$ & $0.48(0.17) \mathrm{Ca}$ & $0.29(0.03) \mathrm{Da}$ & $0.32(0.07) \mathrm{Ca}$ \\
B. thuringiensis & $2.35(0.05) \mathrm{ABb}$ & $3.56(0.27) \mathrm{Aa}$ & $2.37(0.25) \mathrm{ABb}$ & $0.45(0.08) \mathrm{Cc}$ \\
Indoxacarb & $0.67(0.26) \mathrm{CDa}$ & $0.6(0.11) \mathrm{Ca}$ & $0.58(0.03) \mathrm{Da}$ & $0.79(0.19) \mathrm{Ca}$ \\
Chlorpyrifos & $1.57(0.46) \mathrm{BCa}$ & $1.23(0.06) \mathrm{BCab}$ & $1.33(0.17) \mathrm{Bab}$ & $1.19(0.01) \mathrm{BCab}$ \\
Lambda-cyhalotrin & $2.79(0.2) \mathrm{Aab}$ & $1.08(0.34) \mathrm{BCc}$ & $3.27(0.18) \mathrm{Aa}$ & $2.04(0.60) \mathrm{Bb}$ \\
Chlorantraniliprole & $0.70(0.25) \mathrm{CDc}$ & $1.95(0.08) \mathrm{Bb}$ & $2.30(0.59) \mathrm{ABb}$ & $4.95(0.32) \mathrm{Aa}$ \\
Spinosad & $0.76(0.06 \mathrm{CDa}$ & $0.8(0.2) \mathrm{Ca}$ & $0.59(0.13) \mathrm{Da}$ & $0.65(0.07) \mathrm{Ca}$ \\
\hline CV(\%) & & & & 28.67 \\
\hline
\end{tabular}

Means followed by the same upper-case letter on the column and lower-case letter on the row do not differ according to Tukey's test at $p$ $\geq 0.05$.

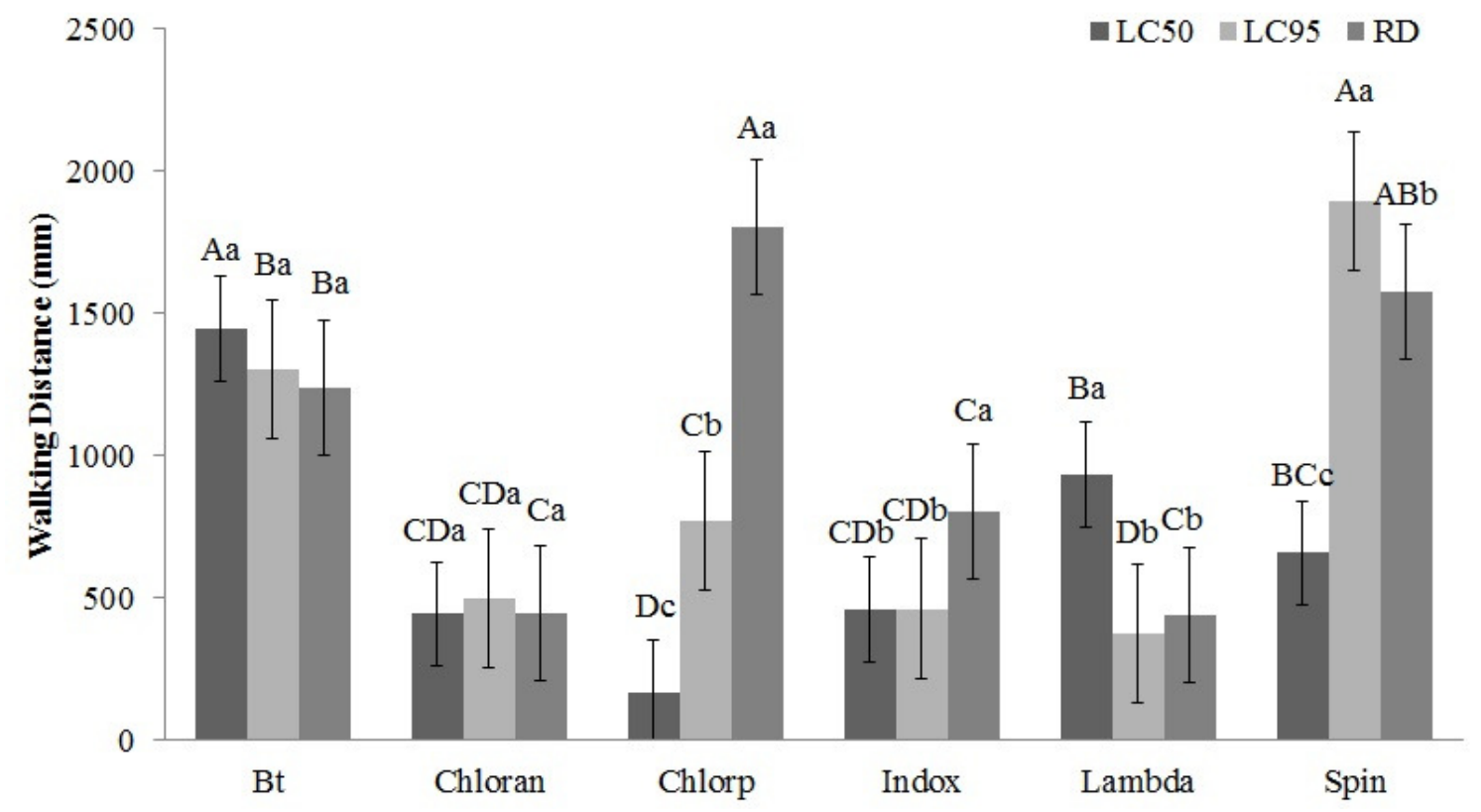

Figure 1. Walked distance (mm) by Helicoverpa armigera on a surface treated with $\mathrm{LC}_{50}, \mathrm{LC}_{95}$ and the recommended dose $(\mathrm{RD})$ of the insecticides $(B t=$ B.thuringiensis; Chloran= Chlorantraniliprole; Chlorp $=$ Chlorpyrifos; Indox $=$ Indoxacarb Lambda $=$ Lambda-cyhalotrin e Spin= Spinosad). Means \pm standard error followed by the same letters - upper case for insecticides, and lower case for concentrations - do not differ, according to Tukey's test, at $5 \%$ of probability.

The walking speed by $H$. armigera observed for $\mathrm{LC}_{50}$ was higher for lambda-cyhalothrin treatment, in the $\mathrm{LC}_{95}$ and $\mathrm{DR}$ the rate was higher for chlorpyrifos followed by spinosad; in the DR the walking speed was higher in B. thuringiensis and chlorantraniliprole (Figure 2).

The resting time was higher in the $\mathrm{LC}_{50}$ for the chlorantraniliprole and indoxacarb treatments; for the $\mathrm{LC}_{95}$ it was indoxacarb, spinosad and chlorantraniliprole that have longer time; in the DR the resting time was higher for $B$. thuringiensis.
Regarding the concentrations, the treatments with the $\mathrm{LC}_{50}$ have a longer rest period, except for chlorpyrifos and spinosad that the rest time was higher in $\mathrm{LC}_{95}$ (Figure 3).

The amount of time on a surface treated in the LC50 was lower only for chlorpyrifos, in c195 the time in area treated with lambda-cyhalothrin and $B$. thuringiensis was superior to the other treatments. The proportion of time in the DR treated area was lower for chlorantraniliprole and spinosad (Figure 4). 


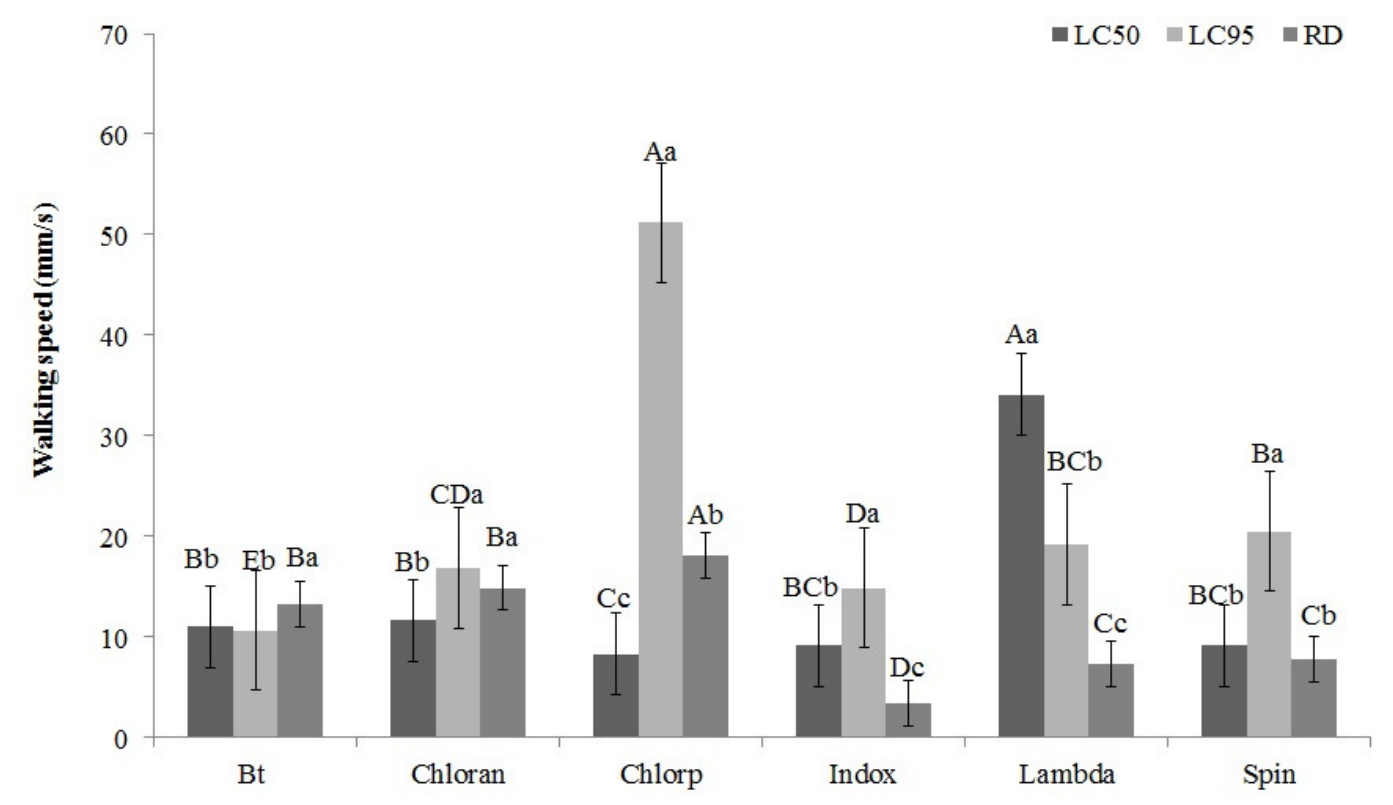

Figure 2. Walking speed $(\mathrm{mm} / \mathrm{s})$ of Helicoverpa armigera on a surface treated with $\mathrm{LC}_{50}, \mathrm{LC}_{95}$ and the recommended dose $(\mathrm{RD})$ of the insecticides $(B t=$ B.thuringiensis; Chloran= Chlorantraniliprole; Chlorp $=$ Chlorpyrifos; Indox $=$ Indoxacarb; Lambda $=$ Lambda-cyhalotrin e Spin $=$ Spinosad). Means \pm standard error followed by the same letters - upper case for insecticides, and lower case for concentrations - do not differ, according to Tukey's test, at $5 \%$ of probability.

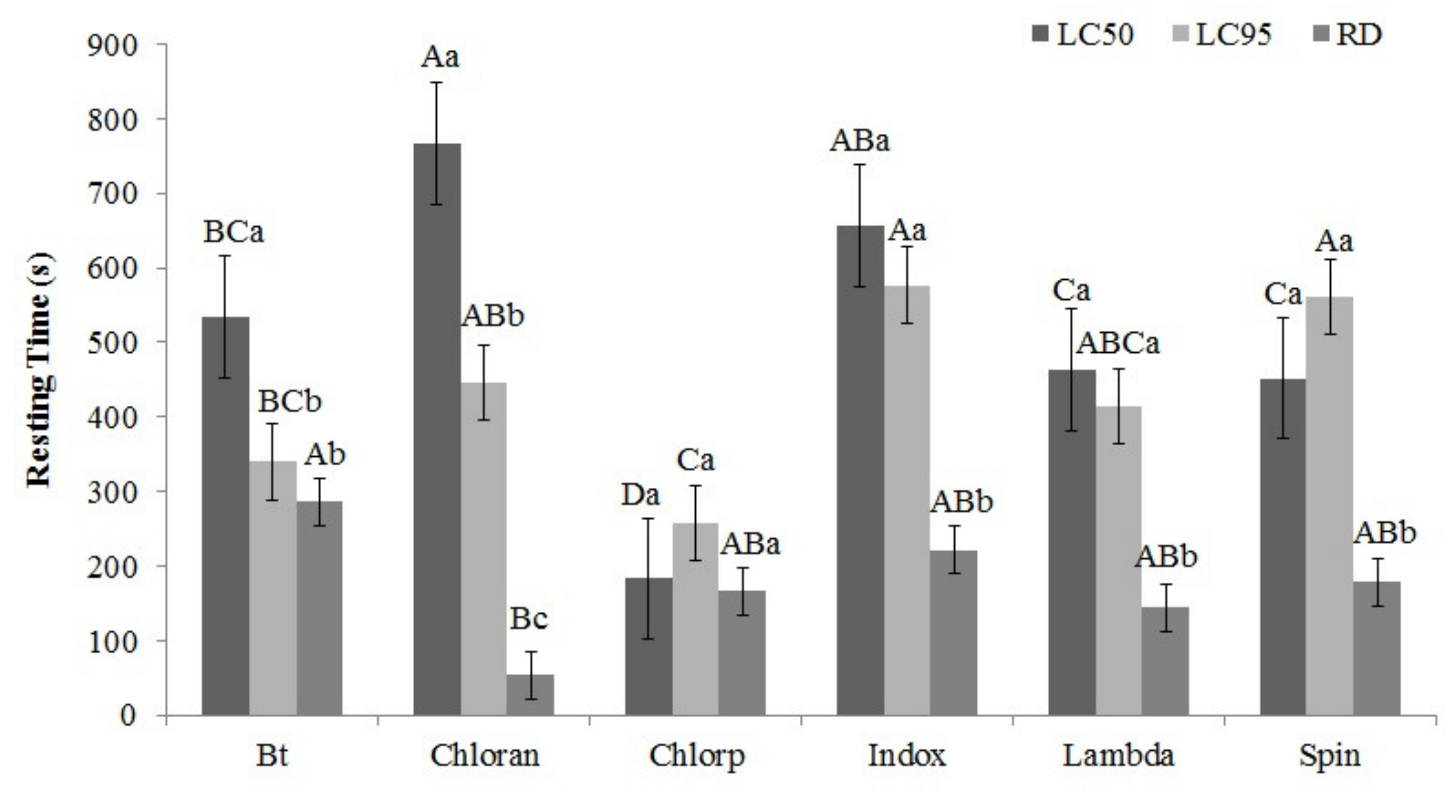

Figure 3. Resting time (s) of Helicoverpa armigera on a surface treated with $\mathrm{LC}_{50}, \mathrm{LC}_{95}$ and the recommended dose (RD) of the insecticides $(\mathrm{Bt}=$ B.thuringiensis; Chloran= Chlorantraniliprole; Chlorp= Chlorpyrifos; Indox= Indoxacarb; Lambda= Lambda-cyhalotrin e Spin= Spinosad). Means \pm standard error followed by the same letters - upper case for insecticides, and lower case for concentrations do not differ, according to Tukey's test, at $5 \%$ of probability. 


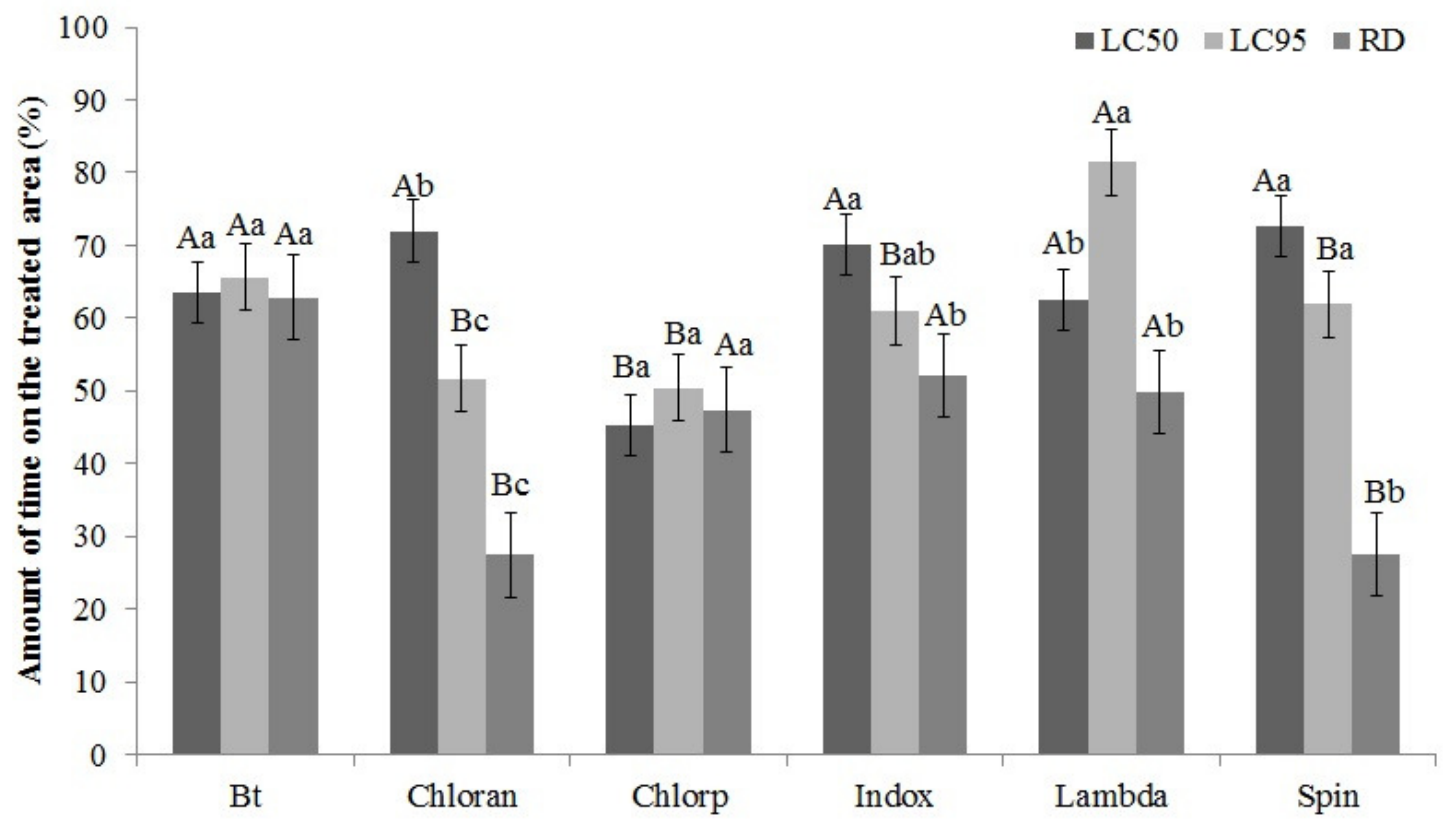

Figure 4. Amount of time (\%) of Helicoverpa armigera on a surface treated with $\mathrm{LC}_{50}$, $\mathrm{LC}_{95}$ and the recommended dose $(\mathrm{RD})$ of the insecticides $(B t=$ B.thuringiensis; Chloran= Chlorantraniliprole; Chlorp $=$ Chlorpyrifos; Indox $=$ Indoxacarb; Lambda $=$ Lambda-cyhalotrin e Spin $=$ Spinosad). Means \pm standard error followed by the same letters - upper case for insecticides, and lower case for concentrations - do not differ, according to Tukey's test, at $5 \%$ of probability.

\section{DISCUSSION}

Insecticide resistance has a great impact on pest control and threatens agriculture. Diverse molecular mechanisms underlie metabolic and target site insecticide resistance (HECKEL, 2010). Different resistance mechanisms have been reported for $H$. armigera to the main chemical groups, including target site insensitivity, metabolism by carboxylesterases, and P450s (DALY; FISK, 1992; GUNNING, 1996; GUNNING et al., 1996; RANASINGHE; HOBBS, 1999; GUNNING et al., 2007).

In this study, $B$. thuringiensis needed high concentrations to cause mortality $\mathrm{LC}_{50}$ and $\mathrm{LC}_{95}$ (Table 2).The bio-insecticide is an alternative to neurotoxic insecticideswith an excessive increase of the pressure selection of insect pests. The pressure becomes a higher concern, since in addition to its application by pulverization, its toxin is also introduced in plants through the bacterial crystals, to promising and efficient alternative to control some lepidopterans (SCHÜNEMANN et al., 2014).

Bacillus thuringiensis and chlorpyrifos showed higher $\mathrm{LC}_{50}$ and $\mathrm{LC}_{95}$ values than those recommended by the manufacturer, as well as increased alpha and beta esterase activity. The high the alpha and beta esterase activity observed in $H$. armigera population indicates a higher metabolic rate, which may mean some level of resistance, a likely consequence of a long period of exposure to organophosphate, pyrethroids and cry toxin, for example (ODHIAMBO et al., 2010; DAWKAR et al., 2016). These enzymes are able to metabolize the insecticides, due to the high expression of the genes that codify them.

Some chemical compounds can stimulate or even reduce the mobility of insects, affecting their behavior of locomotion. Different behavioral patterns of walking were observed (distance traveled, walking speed and rest time) for $H$. armigera exposed to different classes of insecticides; there was also a change in behavior depending on the concentration used. The characteristics of the $H$. armigera walking behavior in the treated area can be explained by differences in the way insecticides act and at the destination, which can lead to an intensification or reduction of responses. These changes can act as a defense mechanism for the deleterious effects caused by insecticide. Behavioral changes may also be associated with the neurotoxic action of the insecticide, which affects the motor coordination, repellency or irritant effect of pesticides (DESNEUX et al., 2007; YU, 2008).

The reduced mobility of insects exposed to neurotoxic insecticides is a common behavior since neurotoxic activity is associated with loss of motor coordination. The larvae of Spodoptera frugiperda (JE Smith) (Lepidoptera: Noctuidae) resistant to 
carbaryl were able to avoid feeding on leaves treated with this insecticide, creating low mortality when compared to susceptible larvae. Young and Mcmiliam (1979), Luong et al. (2017) observed that, the larvae that moved off $B t$ diet were more likely to survive when they subsequently relocated on to diet without Bt. These findings contribute to current research in behavioral resistance of $H$. armigera larvae to understand how Bt-susceptible first-instar larvae can establish their feeding on $B t$ cotton plants. These results suggest that there might be lower survival in some situations in $B t$-resistant larvae compared with $B t$-susceptible larvae, and this may favour a delay in resistance evolution.

Behavioral resistance is determined by actions that influence the response of the organism at selective pressures caused by a given insecticide, increasing the capacity of an insect population to escape the lethal effects of the insecticide and may be related to the insect's learning ability (HOY et al., 1998). According to (CORDEIRO et al., 2010) the perception of insecticides by sensillas was reduced for the species Ceraeochrysa cubana (Hagen) (Neuroptera: Chrysopidae). Therefore, the population preserves its intrinsic susceptibility to the insecticide, however, the insect changes his behavior to avoid contact with insecticide.

Helicoverpa armigera exposed to chlorpyrifos, lambda-cyhalothrin and $B$. thuringiensis insecticides showed increased biochemical activity and potential risk of metabolic resistance. Regarding walking behavior, the results corroborate biochemical activities, where $H$. armigera presented resistance behavior to the insecticides. The behavioral characteristics observed are related to the mode of action of the insecticide and the selection pressure that can result in a greater tolerance to the action of these products. From the results obtained, it is noted that showed that management strategy should be developed based on the rotation with insecticides of different modes of action and doses that currently present control efficiency, since the doses of some of the insecticides were not effective.

The regular monitoring of population distribution and frequency may have important implications for the resistence of $H$. armigera in Brazil. This research has provided perspectives for additional studies, such as the monitoring of the behavioral and physiological resistance to insecticides of the next generations of $H$. armigera, as well as characterization of esterases to better understand the functioning of esterases in the role of detoxification.

\section{ACKNOWLEDGEMENTS}

The authors thank the Foundation of Amparo the Research of Piauí - FAPEPI, for granting the scholarship to the first author. To Federal University of Pernambuco for technical and material assistance to carry out the biochemical analysis.

RESUMO: A toxicidade de alguns inseticidas a Helicoverpa armigera foi estudada através de efeitos subletais, avaliando a atividade enzimática da esterase e a resposta comportamental. A formulação comercial dos inseticidas selecionados foram clorpirifos, espinosad, indoxacarb, clorantraniliprole, lambda-cialotrina e Bacillus thuringiensis utilizados pelos agricultores para controle de $H$. armigera. Para determinar a atividade da esterase, as larvas foram alimentadas com discos de folha de soja mergulhados em solução de inseticida usando a concentração letal $\left(\mathrm{CL}_{50}\right)$. Para os testes de características comportamentais, papel filtro foi imerso em três concentrações de inseticidas ( $\mathrm{CL}_{50}, \mathrm{CL}_{95}$ e dose recomendada), posteriormente o comportamento das larvas foi observado em Videomex-One. Os resultados para a atividade enzimática mostraram aumento da atividade da esterase, com variação ao longo dos tratamentos e do tempo de exposição dos insetos aos inseticidas. Com exceção do spinosad, outros inseticidas mostraram um aumento na atividade EST- $\alpha, 6$ e 24 horas após o contato das lagartas com inseticida. Diferentes padrões comportamentais de caminhada (distância percorrida, velocidade de caminhada e tempo de repouso) para $H$. armigera exposto a diferentes classes de inseticidas. $H$. armigera exposta aos inseticidas clorpirifos, lambda-cialotrina e $B$. thuringiensis mostraram maior atividade da esterase. Em relação ao comportamento ambulante, os resultados confirmam a atividade enzimática, onde $H$. armigera teve alteração comportamental após exposição ao inseticida.

PALAVRAS-CHAVE: Destoxicação. Atividade enzimática. Resistência. Efeitos subletais. 


\section{REFERENCES}

CHAREONVIRIYAPHAP, T.; BANGS, M. J.; SUWONKERD, W.; KONGMEE, M.; CORBEL, V.; NGOENKLAN, R. Review of insecticide resistance and behavioral avoidance of vectors of human diseases in Thailand. Parasites \& Vectors, v. 6, p. 1-28, 2013. https://dx.doi:10.1186/1756-3305-6-280.

COOPERBAND, M. F.; ALLAN, S. A. Effects of different pyrethroids on landing behavior of female Aedes aegypti, Anopheles quadrimaculatus, and Culex quinquefasciatus mosquitoes (Diptera: Culicidade). Journal of Medical Entomology, v. 46, p.292-306, 2009. https://doi.org/10.1603/033.046.0214

CORDEIRO, E. M. G.; CORRÊA, A. S.; VENZON, M.; GUEDES, R. N. C. Insecticide survival and behavioral avoidance in the lacewings Chrysoperla externa and Ceraeochrysa cubana. Chemosphere, v. 81, p. 1352-1357, 2010. https://doi.org/10.1016/j.chemosphere.2010.08.021

CUNNINGHAM, J. P.; ZALUCKI, M. P. Understanding heliothines (Lepidoptera: Noctuidae) pests: what is a host plant? Journal of Economic Entomology, v. 107, p. 881-896, 2014. https://doi.org/10.1603/EC14036

DALY, J. C.; FISK, J. H. Inheritance of metabolic resistance to the synthetic pyrethroids in Australian Helicoverpa armigera (Lepidoptera: Noctuidae). Bulletin of Entomological Research, v. 82, p. 5-12, 1992. https://doi.org/10.1017/S0007485300051439

DAWKAR, V. V.; CHIKATE, Y. R.; MORE, T. H.; GUPTA, V. S.; GIRI, A.P. The expression of proteins involved in digestion and detoxification are regulated in Helicoverpa armigera to cope up with chlorpyrifos insecticide. Insect Science, v. 23, p. 68-77, 2016. https://dx. doi: 10.1111/1744-7917.12177.

DESNEUX, N.; DECOURTYE, A.; DELPUECH, J. M. The sublethal effects of pesticides on beneficial arthropods. Annual Review of Entomology, v. 52, p. 81-106, 2007.

https://doi.org/10.1146/annurev.ento.52.110405.091440

DOWNES, S. J.; MAHON, R.; ROSSITER, L.; KAUTER, G.; LEVEN T.; FITT, G.; GEOFF, B. Adaptive management of pest resistance by Helicoverpa species (Noctuidae) in Australia to the Cry2Ab Bt toxin in Bollgard IIß cotton. Evolutionary Applications, v. 3, p. 574-584, 2010. https://dx.doi: 10.1111/j.17524571.2010.00146.x

FINNEY, D. J. Probit Analysis, England, London, 1971.

FITT, G. P.; WILSON, L. J. Genetic engineering in IPM: Bt cotton, in: Kennedy GG, Sutton TB (Eds.) Emerging Technologies in Integrated Pest Management: Concepts, Research and Implementation APS Press, St Paul, MN, USA, v.1 p.108-125, 2000.

FORRESTER, N. W.; CAHILL, M.; BIRD, L. J.; LAYLAND, J. K. Management of pyrethroid and endosulfan resistance in Helicoverpa armigera (lepidoptera: Noctuidae) in Australia. Bulletin of Entomological Research, 1, 1-132, 1993. https://doi.org/10.1017/S1367426900000072

GUNNING, R. V. Bioassay for detecting pyrethroid nerve insensitivity in Australian Helicoverpa armigera (Lepidoptera: Noctuidae). Journal of Economic Entomology, v. 89, p. 816-819, 1996. https://doi.org/10.1093/jee/89.4.816

GUNNING, R. V., MOORES, G. D.; DEVONSHIRE, A. L. Esterases and esfenvalerate resistance in Australian Helicoverpa armigera (Hübner) Lepidoptera: Noctuidae. Pesticide Biochemistry and Physiology, v. 54, p. 12-23, 1996. https://doi.org/10.1006/pest.1996.0004 
GUNNING, R.V.; DANG, H. T.; KEMP, F. C.; NICHOLSON, I. C.; MOORES, G. D. New resistance mechanism in Helicoverpa armigera threatens transgenic crops expressing Bacillus thuringiensis Cry1 Ac toxin. Applied and Environmental Microbiology, v. 71, p. 2558-2563, 2005.

https://doi.org/10.1128/AEM.71.5.2558-2563.2005

GUNNING, R. V.; DEVONSHIRE, A. L.; MOORES, G. D. Metabolism of esfenvalerate in pyrethroid susceptible and resistant Australian Helicoverpa armigera. Pesticide Biochemistry Physiology, v. 54, p. 1-12, 1995. https://doi.org/10.1006/pest.1995.1020

GUNNING, R. V.; EASTON, C. S. Endosulfan resistance in Helicoverpa armigera. Bulletim of the Entomological Society of America, v. 33, p. 1-9, 1994.

GUNNING, R. V.; MOORES, G. D.; JEWESS, P.; BOYES, A. L.; DEVONSHIRE, A. L.; KHAMBAY, B. P. Use of pyrethroid analogues to identify key structural features for enhanced esterase resistance in Helicoverpa armigera (Hübner) (Lepidoptera: Noctuidae) Pest Management Science Journal, v. 63, p. 569-575, 2007. https://doi.org/10.1002/ps.1377

HECKEL, D. G. Molecular genetics of insecticide resistance in Lepidoptera. In: Goldsmith, M. R, Marec F, editors. Molecular Biology and Genetics of the Lepidoptera, v. 8, p. 239-269, 2010.

HECKEL, D. G.; GAHAN, L. J.; DALY, J. C.; TROWELL, S. A genomic approach to understanding Heliothis and Helicoverpa resistance to chemical and biological insecticides. Philosophical transactions of the Royal Society the London B: Biological Science, v. 353, p. 1713-1722, 1998. https://doi.org/10.1098/rstb.1998.0323

HIROSE, E.; MOSCARDI, F. Insetos de outras regiões do mundo: Ameaças. In Hoffmanm-Campo, C.B., Corrêa-Ferreira B. S., Moscardi, F (Ed). Soja: Manejo integrado de insetos e outros artrópodes-praga. Pesquisa Agropecuaria Brasileira, v. 1, p. 445-492, 2012.

HOY, C. W., HEAD, G. P.; HALL, F. R. Spatial heterogeneity and insect adaptation to toxins. Annual Review of Entomology, v. 43, p. 571-594, 1998. https://doi.org/10.1146/annurev.ento.43.1.571

KASTEN JÚNIOR, P.; PRECETTI, A. A. C. M.; PARRA, J. R. P. Dados biológicos comparativos de Spodoptera frugiperda (J. E. Smith, 1797) em duas dietas artificiais e substrato natural. Revista de Agricultura, 53, 68-78, 1978.

KRITICOS, D. J.; OTA, N.; HUTCHISON, W. D.; BEDDOW, J.; WALSH, T.; BORCHERT, D. M.; PAULAMOREAS, S. V.; CZEPAK, C.; ZALUCKI, M. P. The Potential Distribution of Invading Helicoverpa armigera in North America: Is It Just a Matter of Time? PLoS ONE, v. 10, e0133224, 2015. https://dx.doi:10.1371/journal.pone.0119618.

LI, X.; SCHULER, M. A.; BERENBAUM, M. R. Molecular mechanisms of metabolic resistance to synthetic and natural xenobiotics. Annual Review of Entomology, v. 52, p. 231-253, 2007.

https://doi.org/10.1146/annurev.ento.51.110104.151104

LOWRY, O. H.; ROSEBROUGH, N. I.; FARR, A. L.; RANDALL, R. J. Protein measurement with the Folin phenol reagent. Journal of Biological Chemistry, v. 193, p. 265-275, 1951.

LUONG, T. T. A.; ZALUCKI, M. P.; PERKINS, L. E.; DOWNES, S. J. Feeding behaviour and survival of Bacillus thuringiensis-resistant and Bacillus thuringiensis-susceptible larvae of Helicoverpa armigera (Lepidoptera: Noctuidae) exposed to a diet with Bacillus thuringiensis toxin. Australian Entomological Society, v. 1, p. 1-8, 2017. https://dx.doi: 10.1111/aen.12265. 
MCALLISTER, J. C.; GODSEY, M. S.; MARIAH, L. S. Pyrethroid resistance in Aedes aegypti and Aedes albopictus from Port-au- Prince, Haiti. Vector Ecology Journal, v. 37, p. 325-332, 2012. https://doi.org/10.1111/j.1948-7134.2012.00234.x

MCCAFFERY, A.R. Resistance to insecticides in Heliothine Lepidoptera: a global view. Philosophical Transactions of the Royal Society B: Biological Sciences, v. 353, p. 1735-1750, 1998. https://dx.doi:10.1098/rstb.1998.0326.

MURÚA, M. G.; SCALORA, F. S.; NAVARRO, F. R.; CAZADO, L. E.; CASMUZ, A.; VILLAGRÁN, M. E.; LOBOS, E.; GASTAMINZA, G. First Record of Helicoverpa armigera (Lepidoptera: Noctuidae) in Argentina. Florida Entomologist, v. 97, p. 854-856, 2014. https://doi.org/10.1653/024.097.0279

NANSEN, C.; BAISSAC, O.; NANSEN, M.; POWIS, K.; BAKER, G. Behavioral Avoidance - Will Physiological Insecticide Resistance Level of Insect Strains Affect Their Oviposition and Movement Responses? PLoS ONE, v. 11, e0149994, 2016. https://dx.doi:10.1371/journal.pone.0149994

ODHIAMBO, J. A. O.; GBEWONYO, W. S. K.; OBENG-OFORI, D.; WILSON, M. D.; BOAKYE, D. A.; BROWN, C. Resistance of diamondback moth to insecticides in selected cabbage farms in southern Ghana. International Journal of Biology and Chemical Science, v. 4, p. 1397-1409, 2010.

RANASINGHE, C.; HOBBS, A. A. Induction of cytochrome P450 CYP6B7 and cytochrome b5 mRNAs from Helicoverpa armigera (Hubner) by pyrethroid insecticides in organ culture. Insect Molecular Biology, v. 8, p. 443-447, 1999. https://doi.org/10.1046/j.1365-2583.1999.00135.x

SAS INSTITUTE. User's manual, version 9.1. In: (Ed). SAS Institute. Cary: NC, 2002.

SCHÜNEMANN, R.; KNAAK, N.; FIUZA, L. M. Mode of Action and Specificity of Bacillus thuringiensis Toxins in the Control of Caterpillars and Stink Bugs in Soybean Culture. ISRN Microbiology, v. 135675, p. 112, 2014. https://dx.doi: org/10.1155/2014/135675.

SENAVE. Senave en alerta tras ingreso de peligrosa plaga agrícola, 2013. http://www.abc.com.py/edicionimpresa/economia/senave-en-alerta-trasingreso-de-peligrosa-plaga-agricola-629240. Acessed 25 jul 2014.

SPECHT, A.; GÓMEZ, D. R. S.; MORAES, S. V. P.; YANO, S. A. C. Identificação morfológica e molecular de Helicoverpa armigera (Lepidoptera: Noctuidae) e ampliação de seu registro de ocorrência no Brasil.

Pesquisa Agropecuaria Brasileira, v. 48, p. 689-692, 2013. https://doi.org/10.1590/S0100204X2013000600015

TABASHNIK, B. E.; WU, K.; WU, Y. Early detection of field-evolved resistance to Bt cotton in China: Cotton bollworm and pink bollworm. Journal of Invertebrate Pathology , v. 110, p. 301-306, 2012. https://doi.org/10.1016/j.jip.2012.04.008

TAY, W. T.; SORIA, M. F.; WALSH, T.; THOMAZONI, D.; SILVIE, P.; BEHERE, G. T.; CRAIG, A.; DOWNES, S. A Brave New World for an Old World Pest: Helicoverpa armigera (Lepidoptera: Noctuidae) in Brazil. PLoS ONE, v. 8, e80134, 2013. https://dx.doi:10.1371/journal.pone.0080134.

YOUNG, J. R.; MCMILIAM, W. W. Differential feeding by two strains of fall army worm larvae on carbaryl treated surfaces. Journal of Economic Entomology, v. 72, p. 202-203, 1979.

https://doi.org/10.1093/jee/72.2.202

YU, S. J. Principles of pesticide metabolism. Toxicology and Biochemistry of Insecticides, Nova York, 2008, $276 \mathrm{p}$. 